日臨外会誌 64 (12)，3101-3104, 2003

症例

傍ストーマヘルニア嵌頓の 1 例

新潟臨港総合病院外科, 新潟大学大学院医歯学総合研究科消化器 - 一般外科学分野 (第 1 外科)* 大矢洋小林孝松尾仁之鼻山勝義*

消化管ストーマの合併症で傍ストーマヘルニアは比較的多いが嵌頓することは稀であ る. 今回われわれは, 傍ストーマヘルニア嵌頓に陥り緊急手術を要した症例を経験した ので報告する. 症例は72墄, 女性. 平成 6 年直腸癌で腹会陰式直腸切断術が施行され $\mathrm{S}$ 状 結腸瘦が造設された。平成11年 5 月13日左側腹部痛, 嘔吐を主訴に来院した. 腹部 CT で ストーマ近傍皮下に㹡張した腸管を認め, 傍ストーマヘルニア嵌頓による絞拒性イレウ スと診断し緊急手術施行した. 術中所見で, ストーマの位置は腹直筋外縁でその頭側に ヘルニア門があり嵌頓した小腸を認めたため, 絞扼解除・ヘルニア修復術を施行した。 本症例のヘルニア発生原因としては，1）患者が肥满体であった，2）ストーマ作製位 置が腹直筋外縁であった，と考えられた．傍ストーマヘルニアを予防するためには，腹 直筋中央を貫くストーマを確実な手技で造設することが肝要と思われた。

索引用語：傍ストーマヘルニア, 絞拒性イレウス

\section{はじめに}

消化管ストーマ造設後の後期合併症の中で傍ストー マヘルニアは比較的頻度が高いが嵌頓することは稀て ある”.今回われわれは絞拒性イレウスに陥り，緊急手 術を要した傍ストーマヘルニア嵌頓の 1 例を経験した ので報告する。

症例 : 72歳, 女性.

主訴：左側腹部痛, 嘔吐.

家族歴：特記すべきことなし。

既往歴: 平成 6 年 2 月 14 日直腸癌で腹会陰式直腸切 断術が施行され S 状結腸瘦が造設された。平成 9 年 9 月24日転移性肝癌で肝部分切除術が施行された。平成 9 年11月 4 日肝動注りザーバー留置し化学療法施行, その後再発は認めていない。

現病歴: 平成 11 年 5 月 13 日昼食後, ストーマ周囲の 左側腹部痛が出現し当科外来を受診した。保存的治療 で一時的に軽快したが，その後排ガス・排便なく腹痛 が增強し，嘔吐も加わったため5月15日イレウスの診 断で緊急入院となった。

2003 年 6 月 30 日受付 2003 年 8 月 20 日採用

〈所属施設住所〉

₹950-0051 新鼬市桃山町 1-114-1
入院時現症：身長 $144.3 \mathrm{~cm}$, 体重 $51.8 \mathrm{~kg}$, 栄養状態 良好で肥満 $(+)$. 腹部は全体的に軽度膨満していた。 ストーマ周囲に硬い腫瘤を触知し，同部位に圧痛を認 めた。

入院時検查所見 : 白血球数 $6,300 / \mathrm{mm}^{3}, \mathrm{CRP}<0.25$ $\mathrm{mg} / \mathrm{dl}$ で正常範囲にあっだ. 他, 特記すべき異常はな かった.

腹部単純 X 線検查：小腸の拡張像および鏡面像を 認めた（図 1 ).

腹部 CT 検查 : ストーマ造設部位に腹壁欠損を認 め,ヘルニア堡とその内部に拡張腸管を認めた（図 2 ). 以上より傍ストーマヘルニア嵌頓と揨断し，用手的に 脱出腸管の還納を試みたが僄納できず，平成11年 5 月 17日緊急手術を施行した。

手術所見：ストーマ上縁より約 $2 \mathrm{~cm}$ 頭側で皮膚割 線に浻った皮闻切開を加え，ヘルニア衰とヘルニア門 を露出した。、ルニア襄は腹膜からなり，ヘルニア門 の大きさは直径約 $2 \mathrm{~cm}$ でストーマは腹直筋外緑に存 在した、ヘルニア䧶を開くとその内容は大網と小腸で, 小腸は血行障害を認め絞扼性イレウスと診断された。 ヘルニア門を切開し絞扼を解除すると, 小腸の血行障 害は消失し敗死腸管を認めなかったため，小腸は切除 せず腹腔内へ還納した（図 3 )。へルニア萣は一部切除 した.ヘルニア門は合成吸収系を用いて筋膜の前䩪と 


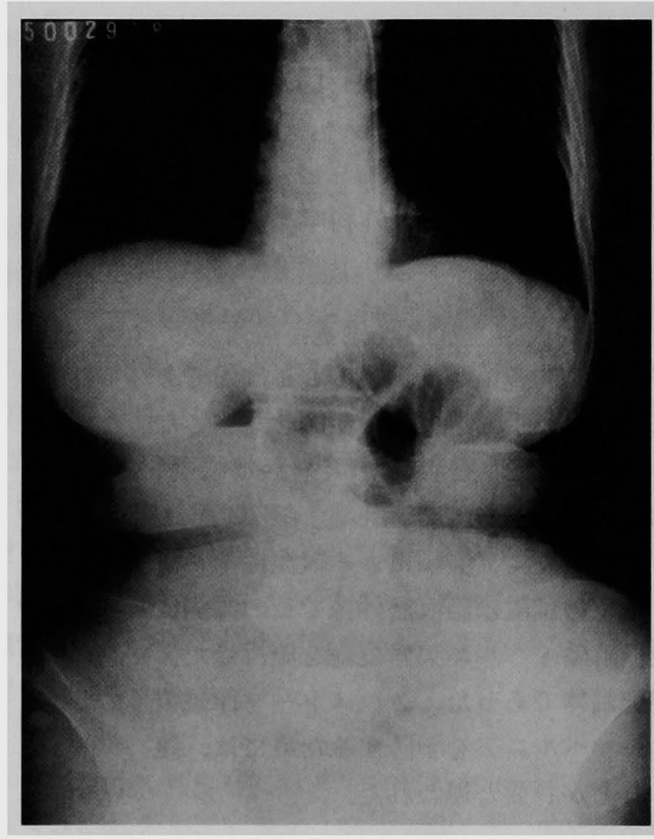

図 1 腹部単純 X 線検査：小腸の拡張像および鏡面 像を認めた。

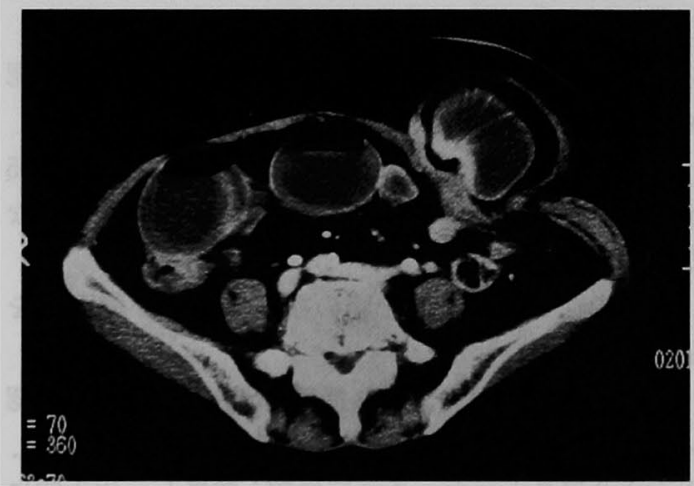

图 2 腹部 CT 検査：ストーマ近傍の腹壁欠損部より脱 出したヘルニア京と，その内部に拡張腸管を認めた。

後鞘を別々に縫縮して閉鎖した.

術後経過：術後経過は順調で 6 月10日退院となっ た. 現在, 術後 4 年でへルニア再発は認めていない.

\section{考 察}

ストーマ造設に伴う合併症としては，傍ストーマへ ルニア，狭窄，脱出，閉塞，宿没，周囲皮虐のただれ， などが挙げられる213).これらの合併症の中で傍ストー マヘルニアの発生頻度は比較的高く，全ストーマの 5 〜36\%に発症しストーマ合併症の 40～50\%を占めると

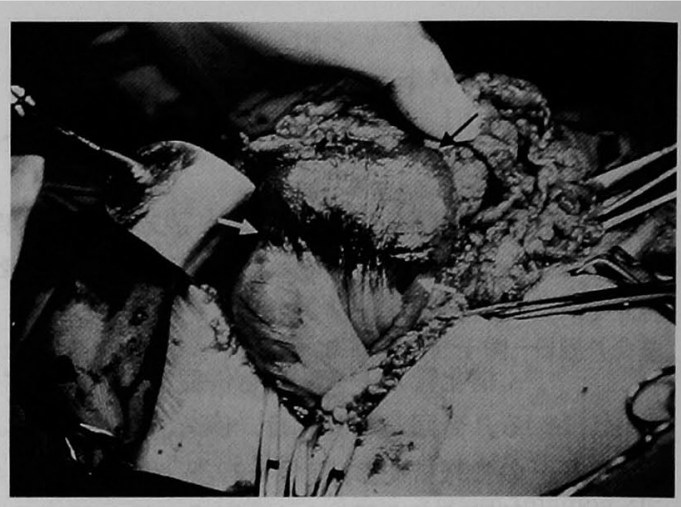

図 3 手術所見：ヘルニア門を切開し絞捱を解除すると 脱出小腸 (黒矢印) の血行障害は消失し，壊死腸管を認 めなかった（白矢印：絞扼部)。

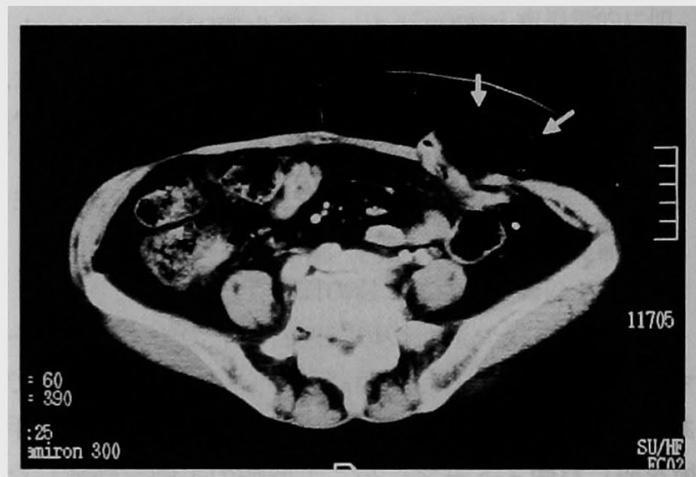

図 4 直腸癌術後 2 年 8 カ月の腹部 CT 検査：すでにス トーマ近傍に皮下まで脱出するへルニア趸 (矢印)を認 めた.

報告されている2144. しかしながら，傍ストーマヘルニ アの大部分は全く症状のないいわゆる不顕性へルニア か，症状が軽く無処置もしくはストーマベルトによる 保存的治療で経過観察できるため，再手術を要するも のは少ない ${ }^{5}$. 再手術を要する傍ストーマへルニアと しては, (1)装具の装着や洗浄が困難(2)へルニア門が狭 くヘルニア内容の還納が困難あるいは不可能(3)へルニ アが大きく美容上問題がある，などが挙げられてい $ろ^{5}$.

また傍ストーマヘルニアのヘルニア門は広いため, ヘルニア内容が嵌頓することは稀と言われてい $3^{144)}$. 本邦における傍ストーマヘルニア嵌頓による緊 急手術は，われわれが検索しえた限り過去 15 年で 5 例

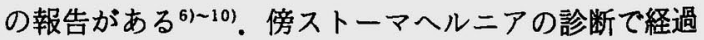
観察中に嵌頓した症例は 1 例6)で，他の症例はイレウ 


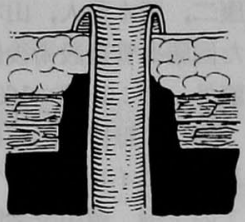

(a)

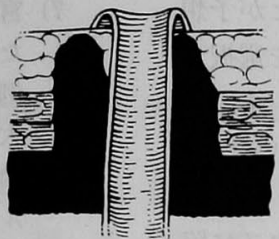

(b)

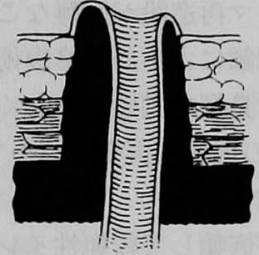

(c)

図 5 傍ストーマヘルニアの分類：a）腹壁を貫くが皮下に達しない もの. b) 腹壁を貫き皮下組織に達するもの. c ) 皮下組織に達しス トーマを持ち上げるもの.

スを発症した時点で初めて傍ストーマヘルニアの存在 に気付かれていた. 本症例もイレウスと診断され入院 した後に施行された腹部 CTで，初めて傍ストーマへ ルニアの存在に気付かれた。しかしながら過去の腹部 $\mathrm{CT}$ を見直してみると, 直腸癌術後 2 年 8 力月の平成 8 年10月の CT ですでにストーマ近傍に皮下まで脱出 するへルニア蒦を認めた(図 4). 傍ストーマヘルニア は衍後 2 年以内に発生することが多い3111と言われて おり, 本症例も症状のない不顕性へルニアが, 術後比 較的早期から存在していたと考えられる.

Leslie $^{5)}$ は, 傍ストーマヘルニアを3つに分類してい る (図 5 ). (a)の interstitial type は不顕性へルニア, (c)の intrastomal type はストーマの脱出に多くみら れ, 本症例は(b)の subcutaneous type に分類されるが, このタイプの傍ストーマヘルニアは嵌頓に楩ることが 多いといわれている.

傍ストーマヘルニア発生の原因は 2 つに分けられ $3^{4) 5)}$. 1 つは患者の状態による要因，もう 1 つは手術 手技による要因である。

患者の状態による要因としては肥満, 慢性閉塞性肺 疾患，咳嗽，腹水など腹圧が高まる病態，あるいは低 栄養,ステロイドなど腹壁の脆弱化をひき起こす病態 が挙げられる。

手術手技による要因としては，(1)過剰な筋膜切開(2) ストーマ造設の不適切な位置(3)筋膜と吊り上げ腸管の 末固定(4)感染の合併などである.これらの原因の中で 特に頻度が高いものは(1)と(2)であり，筋膜切開は指 2 本が根元まで入る大きさが良いとされている12). Sjödahl ら ${ }^{11)}$ は, 経腹直筋に造設したストーマ107例の うち傍ストーマヘルニアが 3 例 $(2.8 \%)$ であったのに 対し，腹直筋外側に造設した23例は 6 例 $(26.1 \%$ ）に 傍ストーマヘルニアが認められ，ストーマは腹直筋内 を通して造設すへきである, と報告している.大木ら ${ }^{12)}$
は,術前の腹部 CT で腹直筋の幅を測定し位置を決め, 腹直筋の中央を貫くストーマを造設する方法を35例施 行し，傍ストーマヘルニアを含む合併症はなかったと 報告している．また，腹直筋外側にストーマを造設す ると傍ストーマヘルニアの頻度が高くなる原因とし て, 真崎ら ${ }^{13)}$ は, 内および外腹斜筋によってストーマが 様々な方向に引つ張られ，同部が時間の経過とともに 次第に大きくなりへルニアが発生する, と論じている.

本症例の傍ストーマヘルニア発生の原因としては, 患者状態に起因するものとして患者が肥満体であった ことおよび手術手技に起因するものとしてストーマ造 設の位置が腹直筋外縁であったことが考えられた，従 つて初回手術時, ストーマ造設の位置を正確に測定し マーキングすることが肝要と考えられた.

傍ストーマヘルニアの修復術式は, 局所修復術とス トーマを別の場所に作り直す再造設術とに分けられ る4)5). 局所修復術としては，直接縫合閉鎖術と mesh を用いた修復補強術が報告されている。

Rubin ら ${ }^{14)}$ の報告では局所修復術の成績は不良で， 初回の修復は再造設術の方を提唱している. 但し, 再 造設術も18例中 6 例 $(33 \%)$ の再発があり，また腹腔 内の広範な痛着や頻回の手術既往がある場合再造設術 は容易でない占. Rosin $5^{15)}$ が局所修復に polypropylene mesh を用いた補強術を報告した以後同様

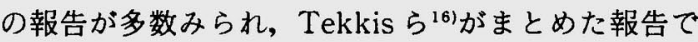
は，72例中再発は 5 例 $(6.9 \%)$ と良好な成績を挙げて いる。しかしながら，補強方法別による術後成績は報 告によって異なり，現在まで標準的な修復術式は確立 していない(16).

本症例では，(1)傍ストーマヘルニア嵌頓による緊急 手術であったため術前の colon preparation が充分で なく，meshを用いた補強術では術後感染の risk があ ること(2)また過去 2 回の開腹手術の既往があるため腹 
腔内の撚着によりストーマ再造設が困難なことが予想 されたため, 直接縫合閉鎖による局所修復術を選択し た. 本症例の術後経過は良好で創感染もなく, 第23病 日に退院した。術後 4 年の現在も再発を認めていない. 結語

傍ストーマヘルニアが嵌頓して絞拒性イレウスに宿 り，緊急手術を施行した1例を経験した，永久的な単 孔式結腸樓を造設する際には，術前の適確なサイトマ ーキングと，確実な手技で腹直筋の中央を貫くストー マを作製することが重要と考えられた。

\section{文献}

1) Keighly MRB, Williams NS : Complications of colostomy. Surgery of the Anus, Rectum and Colon. 2nd Ed, WB Saunders Co., London, 1999, p289-295

2) Londono-Schimmer EE, Leong APK, Phillips RKS : Life table analysis of stomal complications following colostomy. Dis Colon Rectum 37: 916-920, 1994

3) Cheung MT: Complications of an abdominal stoma : an analysis of 322 stomas. Aust NZ J Surg 65: 808-811, 1995

4) Pearl RK : Parastomal hernias. World J Surg $13: 569-572,1989$

5) Leslie D: The parastomal hernia. Surg Clin North Am 64:407-415, 1984

6）安西春幸, 松本 隆, 駒崎敏郎他：傍ストーマへ ルニアにより皎拒性イレウスをきたした1 例. 外 科診璙 $36: 1165-1168,1994$
7）宫本康二，玉木雅人，山本哲也他：イレウスをき たした回腸導管造設術後傍ストーマヘルニアの1 例. 臨外 51:1633-1635，1996

8）大谷 裕, 浅野博昭, 宮口直之地：進行性直腸癌 術後12年目にイレウスにて発症した傍ストーマへ ルニアの1例. 岡山医会誌 $110: 68,1998$

9)片桐美和, 炭山嘉伸, 碓井貞仁他: 傍ストーマへ ルニアに起因するイレウスの1例. 日腹部救急医 会誌 $20: 938,2000$

10）高階謙一郎，樋口濃史，趙 秀之他：イレウスを きたした回腸導管造設後傍ストーマヘルニアの 1 例. 日腹部救急医会誌 $21: 1108,2001$

11) Sjödahl R, Anderberg $B$, Bolin $T$ : Parastomal hernia in relation to site of the abdominal stoma. Br J Surg $75: 339-341,1988$

12）大木繁男, 山口茂樹, 池 秀之他: 左側結腸人工 肛門造設の標準術式. 外科 $64: 423-429,2002$

13）真崎善二郎, 吉田一博, 木下徳雄他：回腸導管造 設術後のパラストーマルヘルニアーその原因と修 復術について一. 泌外 $1: 209-213 ， 1988$

14) Rubin MS, Schoetz DJ, Matthews JB : Is stoma relocation superior to fascial repair? Arch Surg 129: 413-419, 1994

15) Rosin JD, Bonardi RA : Paracolostomy hernia repair with Marlex mesh : a new technique. Dis Colon Rectum $20: 299-302,1977$

16) Tekkis PP, Kocher HM, Payne JG:Paras tomal hernia repair:modified Thorlakson technique, reinforced by polypropylene mesh. Dis Colon Rectum $42: 1505-1508,1999$

\title{
A CASE OF INCARCERATED PARASTOMAL HERNIA
}

\author{
Hiroshi OYA, Takashi KOBAYASHI, Hitoshi MATSUO and Katsuyoshi HATAKEYAMA* \\ Department of Surgery, Niigata Rinko General Hospital \\ -Division of Digestive and General Surgery, Niigata University. Graduate School of Medical and Dental Sciences
}

Parastomal hernia is a relatively frequent complication of intestinal stoma but strangulation of it is rare. We report a case of incarcerated parastomal hernia required an emergency operation. A 72-yearold woman, undergone an abdominoperineal excision of the rectum with end sigmoidostomy for rectal cancer five years earlier, was admitted to the hospital because of left-sided abdominal pain and vomiting. Abdominal CT scan showed peristomal intestinal dilatation in the subcutaneous area. We diagnosed the case as strangulated ileus due to incarcerated parastomal hernia and performed an emergency operation. During surgery, the stoma was situated at the edge of the rectus sheath and the strangulated small intestine was seen beside it. The orifice of the hernia was dilated and repaired locally. It is etiologically thought that the patient's obesity and poor siting of the stoma might cause parastomal hernia in this case. Enterostomy should be constructed by an adequate procedure through the center of the rectus sheath in order to prevent parastomal hernia. 